\title{
Field Efficacy of Different IPM Modules Against Brinjal Shoot and Fruit Borer (BSFB) and The Sucking Insect Pests of Brinjal
}

\author{
U. S. Nayak ${ }^{1 *}$, L. K. Rath ${ }^{2}$, K. Baral ${ }^{3}$ and S. Senapathy ${ }^{3}$ \\ ${ }^{1}$ Regional Research and Technology Transfer Station (OUAT), Ranital, Odisha (756 100), India \\ ${ }^{2}$ Dept. of Entomology, Orissa University of Agriculture and Technology, Bhuabaneswar, Odisha (751 007), India \\ ${ }^{3}$ Palli Siksha Bhaban, Visva Bharati, Sriniketan, West Bengal (731 235), India
}

\section{Article History}

Manuscript No. AR1550a

Received in $14^{\text {th }}$ March, 2016

Received in revised form $26^{\text {th }}$ November, 2016

Accepted in final form $6^{\text {th }}$ December, 2016

\section{Correspondence to}

"E-mail: usnayak74@ gmail.com

\section{Keywords}

Brinjal, BSFB, IPM module, sucking pests, fruit yield

\begin{abstract}
Field experiments carried out to evaluate the efficacy of some IPM modules against Leucinodes orbonalis Guene on brinjal at Keonjhar district of Odisha during 200910 and 2010-11 were also assessed for their efficacy against the sucking insect pests of brinjal. The results indicated that the IPM module comprising of soil application of cartap hydrochloride $4 \mathrm{G} @ 1 \mathrm{~kg}$ a.i. ha ${ }^{-1}$ at 2 weeks of transplanting, intercropping with coriander in 3:1 ratio, alternate foliar spray of indoxacarb 14.5 SC @1 ml l-1 of water and rynaxypyr $20 \mathrm{SC} @ 0.35 \mathrm{ml} \mathrm{l}^{-1}$ of water at 10 days interval twice at vegetative stage and six times commencing from fruiting stage and regular collection and destruction of infested plant parts was found to be highly effective in minimizing the infestation of $L$. orbonalis and resulted in the highest mean fruit yield of $247.57 \mathrm{q}$ $\mathrm{ha}^{-1}$. Whereas, the IPM module consisting of soil application of vermicompost @ $5 \mathrm{t}$ ha $^{-1}$, seedling root dip with solution of Azotobactor, Phosphorous solublising bacteria and Pseudomonas fluorescence, raising maize as barrier crop, alternate application of deltamethrin 2.8 EC @ $1 \mathrm{ml} \mathrm{l}^{-1}$ of water and spinosad $45 \mathrm{SC} @ 0.35 \mathrm{ml} \mathrm{l}^{-1}$ of water at 10 days interval twice at vegetative stage and six times commencing with fruiting stage, foliar application of boron @ 0.25\% Borax (one at vegetative stage and other after flower initiation stage) and regular destruction of infested plant parts afforded maximum control of whiteflies and jassids in brinjal. All the IPM modules significantly brought down pest infestation in brinjal, whereas the maximum pest incidence was observed in the farmers' practice despite repeated application of insecticides.
\end{abstract}

\section{Introduction}

Brinjal Solanum melongena Linn. is one of the most common and popular vegetables grown in the subtropics and tropics and cultivated throughout the year. Heavy incidence of insect pests is one of the major contributing factors towards the low productivity of the crop. According to Patial and Mehta (2008), brinjal is mostly infested by 27 different insect pests (belonging to 8 orders and 20 families) and one mite species. Among these insect pests brinjal shoot and fruit borer (BSFB), Leucinodes orbonalis Guenee is predominant biotic factor contributing up to $20.7-88.7 \%$ loss in fruit yield in various parts of India (Haseeb et al., 2009). Various chemical insecticides have been recommended for the control of this pest and the farmers apply insecticides of different class of chemistry, their combination products and cocktail mixture 15 to 18 times during the cropping season without any appreciable increase in yield. However, indiscriminate application of insecticides for the management of BSFB has resulted in the population build up of sucking pests like jassids (Amrasca biguttula biguttula Ishida) and whiteflies (Bemicia tabaci Genn.) in the brinjal growing areas which offers a new challenge to the farming community. In addition to the substantial negative effects on human health, crop eco-system and surrounding environment, such excessive use of pesticides increase the cost of production making brinjal cultivation expensive for the small and marginal farmers. As IPM can minimize the adverse effects of excessive application of insecticides, the present investigations were carried out to evaluate the efficacy of some IPM modules for the management of BSFB and to study their efficacy against the sucking insect pests like jassids and whiteflies.

\section{Materials and Methods}

Field experiments were conducted during kharif, winter and 
summer seasons of 2009-10 and 2010-11 in the instructional farm of Krishi Vigyan Kendra, Keonjhar, Odisha and three villages namely Basudevpur, Tikarpada and Bhalupali, belonging to medium elevation and medium rainfall Agroecological situations (AES) and each location was considered as one replication. The experiments were laid out separately in two distinct experimental blocks for bio-intensive and chemointensive modules with an isolation distance of $50 \mathrm{~m}$ from each other to avoid the effect of chemicals on pheromone efficiency and bioagent activity in the bio-intensive modules. Thirty days old seedlings of brinjal cv. Blue Star were transplanted in well prepared plots in the farmers' field and KVK instructional farm. The crop was grown with recommended agronomic package of practices and other standard intercultural operations to ensure optimum plant growth. Seven IPM modules were tested against the farmers' practice of indiscriminate application of chemical pesticides and each module was considered as one treatment. The IPM modules tested for their efficacy are depicted in Table 1. All the IPM modules (treatments) were replicated four times in a randomized block design (RBD).

To estimate the comparative efficacy of the IPM modules, treatment and replication wise periodic observations on fruit damage and population level of sucking pests were recorded. The data on damaged and healthy fruits on weight basis were recorded at each picking and cumulative numbers of infested and healthy fruits from all the pickings during different crop seasons were considered to work out the per cent borer infestation. The population level of white fly and jassids were observed on randomly selected 10 plants, from 3 leaves of each plant at weekly interval. The mean population of these sucking

Table 1: IPM Modules tested against L. orbonalis during 2009-10 and 2010-11

Sl. No. IPM modules $\quad$ Details of IPM modules

1. Module $1 \quad$ Soil incorporation of neem cake at transplanting @ $150 \mathrm{~kg} \mathrm{ha}^{-1}+$ Spraying of neemacin (1500 ppm

(Bio-intensive) azadirachitin)@3 $\mathrm{ml} \mathrm{l}^{-1}$ of water at 10 days interval after 15 DAT till last harvest + installation of pheromone traps from 30 DAT@70 ha h $^{-1}$ regular destruction of infested plant parts.

2. Module 2 Soil incorporation of neem cake@ $150 \mathrm{~kg} \mathrm{ha}^{-1}(50 \%$ at transplanting and $50 \%$ at 3 weeks after (Bio-intensive) transplanting)+alternate spraying of neemacin (1500 ppm azadirachitin)@3 ml $\mathrm{l}^{-1}$ of water and Bt $@ 2 \mathrm{~g} \mathrm{l}^{-1}$ of water at 10 days interval twice at vegetative stage and six times commencing with fruiting stage+installation of pheromone traps from 30 DAT@70 ha ${ }^{-1}+$ regular destruction of infested plant parts.

3. Module $3 \quad$ Soil application of neem cake @ $150 \mathrm{~kg} \mathrm{ha}^{-1}$ at 3 weeks after transplanting+foliar spray of 5\% (Bio-intensive) NSKE at 10 days interval from 15 DAT till last harvest+release of bio-agent Trichogramma chilonis (a) 1 lakh ha h $^{-1} 4$ times at 10 days interval+regular destruction of infested plant parts.

4. Module $4 \quad$ Application of Vermicompost @ $5 \mathrm{t} \mathrm{ha}^{-1}$ at transplanting and seedling root dip with solution of Azotobactor (25 $\mathrm{ml} \mathrm{l}^{-1}$ of water), Phosphorous solublising bacteria (PSB) (25 $\mathrm{ml} \mathrm{l}^{-1}$ of water) and Pseudomonas fluorescence ( $3 \mathrm{~g} \mathrm{l}^{-1}$ of water) for 1 hour+raising of barrier crop (2 rows of maize around the field)+alternate application of deltamethrin $2.8 \mathrm{EC} @ 1 \mathrm{ml} \mathrm{1^{-1 }}$ of water and spinosad 45 SC@ $0.35 \mathrm{ml} \mathrm{l}^{-1}$ of water at 10 days interval twice at vegetative stage and six times commencing with fruiting stage+foliar application of boron@ $0.25 \%$ Borax (one at vegetative stage and other after flower initiation stage)+regular destruction of infested plant parts.

5. Module $5 \quad$ Application of carbofuran $3 \mathrm{G} @ 1 \mathrm{~kg}$ a.i ha-1 at 2 weeks after transplanting+Spraying a mixture of cartap hydrochloride@1 $1 \mathrm{~g} \mathrm{l}^{-1}$ of water and diflubenzuron@0.5 $\mathrm{g} \mathrm{l}^{-1}$ of water at 10 days interval twice at vegetative stage and six times commencing with fruiting stage+regular destruction of infested plant parts.

6. Module $6 \quad$ Soil application of fipronil $0.3 \mathrm{G} @ 0.75 \mathrm{~kg}$ a.i. ha ${ }^{-1}$ at 2 weeks of transplanting+intercropping with cluster bean in 3:1 ratio (additive series)+Alternate foliar spray of thiodicarb 75 WP@1.5 $\mathrm{g} \mathrm{l}^{-1} \mathrm{of}^{\circ}$ water and flubendiamide $20 \mathrm{WG} @ 0.4 \mathrm{~g} \mathrm{l}^{-1}$ of water at 10 days interval twice at vegetative stage and six times commencing with fruiting stage+regular destruction of infested shoots and fruits.

7. Module $7 \quad$ Soil application of cartap hydrochloride 4 G@ 1 kg a.i. ha ${ }^{-1}$ at 2 weeks of transplanting+intercropping with coriander in 3:1 ratio (additive series)+alternate foliar spray of indoxacarb $14.5 \mathrm{SC} @ 1 \mathrm{ml} \mathrm{l}^{-1}$ of water and rynaxypyr $20 \mathrm{SC} @ 0.35 \mathrm{ml} \mathrm{l}^{-1}$ of water at 10 days interval twice at vegetative stage and six times commencing from fruiting stage+regular destruction of infested shoots and fruits.

8. Farmers' The farmers mostly relied on the chemicals like carbaryl, chloropyriphos, cypermethrin, fenpractice $\quad$ valarate, malathion, methomyl, monocrotophos, chloropyriphos + cypermethrin, phenthoate, profenophos+cypermethrin and on an average the farmers have gone for 15 rounds of spray during the crop growth period as per their own will. 
pests from all the observations was considered for statistical analysis after necessary data transformation.

\section{Results and Discussion}

The comparative effectiveness of different IPM modules against the fruit infestation caused by BSFB during 2009-10 (pooled mean of three seasons experiment) (Table 2) indicated that all the IPM modules minimized the fruit infestation to a substantial level. Among the IPM modules, significantly superior control of fruit infestation was achieved in the module $\mathrm{M}_{7}$ with a minimum fruit damage of $6.83 \%$ (on weight basis) followed by $\mathrm{M}_{4}$ ( $7.33 \%$ fruit damage), $\mathrm{M}_{6}(7.48 \%$ fruit damage) and $\mathrm{M}_{5}(11.0 \%)$. The modules $\mathrm{M}_{4}$ and $\mathrm{M}_{6}$ had statistically similar efficacy in suppressing the fruit infestation in brinjal.

\begin{tabular}{|c|c|c|c|c|c|c|c|c|c|}
\hline \multirow[t]{2}{*}{ IPM modules } & \multicolumn{4}{|c|}{$\begin{array}{l}\text { Percent fruit damage (weight basis) - } \\
\qquad 2009-10\end{array}$} & \multicolumn{4}{|c|}{$\begin{array}{l}\text { Percent fruit damage (weight basis) - } \\
\qquad 2010-11\end{array}$} & \multirow{2}{*}{$\begin{array}{l}\text { Pooled mean } \\
\text { (2009-10 \& } \\
2010-11)\end{array}$} \\
\hline & Kharif & Rabi & Summer & Pooled mean & Kharif & Rabi & Summer & Pooled mean & \\
\hline $\mathrm{M}_{1}$ & $\begin{array}{l}19.11 \\
(4.37)\end{array}$ & $\begin{array}{l}16.89 \\
(4.11)\end{array}$ & $\begin{array}{l}21.55 \\
(4.64)\end{array}$ & $\begin{array}{l}19.18 \\
(4.38)\end{array}$ & $\begin{array}{l}17.36 \\
(4.17)\end{array}$ & $\begin{array}{l}14.59 \\
(3.82)\end{array}$ & $\begin{array}{l}20.57 \\
(4.53)\end{array}$ & $\begin{array}{l}17.51 \\
(4.18)\end{array}$ & $\begin{array}{l}18.34 \\
(4.28)\end{array}$ \\
\hline $\mathrm{M}_{2}$ & $\begin{array}{l}15.34 \\
(3.92)\end{array}$ & $\begin{array}{l}12.54 \\
(3.54)\end{array}$ & $\begin{array}{l}16.04 \\
(4.00)\end{array}$ & $\begin{array}{l}14.64 \\
(3.83)\end{array}$ & $\begin{array}{l}13.63 \\
(3.69)\end{array}$ & $\begin{array}{l}11.50 \\
(3.39)\end{array}$ & $\begin{array}{l}17.12 \\
(4.14)\end{array}$ & $\begin{array}{l}14.08 \\
(3.75)\end{array}$ & $\begin{array}{l}14.36 \\
(3.79)\end{array}$ \\
\hline $\mathrm{M}_{3}$ & $\begin{array}{l}15.88 \\
(3.98)\end{array}$ & $\begin{array}{l}13.29 \\
(3.64)\end{array}$ & $\begin{array}{l}16.86 \\
(4.11)\end{array}$ & $\begin{array}{l}15.34 \\
(3.92)\end{array}$ & $\begin{array}{l}14.10 \\
(3.75)\end{array}$ & $\begin{array}{l}11.97 \\
(3.46)\end{array}$ & $\begin{array}{l}17.44 \\
(4.18)\end{array}$ & $\begin{array}{l}14.50 \\
(3.81)\end{array}$ & $\begin{array}{l}14.92 \\
(3.86)\end{array}$ \\
\hline $\mathrm{M}_{4}$ & $\begin{array}{c}7.51 \\
(2.74)\end{array}$ & $\begin{array}{c}6.22 \\
(2.49)\end{array}$ & $\begin{array}{l}8.26 \\
(2.87)\end{array}$ & $\begin{array}{c}7.33 \\
(2.71)\end{array}$ & $\begin{array}{c}6.85 \\
(2.62)\end{array}$ & $\begin{array}{c}5.45 \\
(2.33)\end{array}$ & $\begin{array}{l}8.36 \\
(2.89)\end{array}$ & $\begin{array}{c}6.89 \\
(2.62)\end{array}$ & $\begin{array}{c}7.11 \\
(2.67)\end{array}$ \\
\hline $\mathrm{M}_{5}$ & $\begin{array}{l}11.28 \\
(3.36)\end{array}$ & $\begin{array}{c}9.88 \\
(3.14)\end{array}$ & $\begin{array}{l}11.86 \\
(3.44)\end{array}$ & $\begin{array}{l}11.00 \\
(3.32)\end{array}$ & $\begin{array}{l}10.18 \\
(3.19)\end{array}$ & $\begin{array}{c}8.50 \\
(2.91)\end{array}$ & $\begin{array}{l}12.33 \\
(3.51)\end{array}$ & $\begin{array}{l}10.34 \\
(3.21)\end{array}$ & $\begin{array}{l}10.67 \\
(3.27)\end{array}$ \\
\hline $\mathrm{M}_{6}$ & $\begin{array}{c}7.54 \\
(2.74)\end{array}$ & $\begin{array}{c}6.51 \\
(2.55)\end{array}$ & $\begin{array}{c}8.40 \\
(2.90)\end{array}$ & $\begin{array}{c}7.48 \\
(2.74)\end{array}$ & $\begin{array}{c}6.57 \\
(2.56)\end{array}$ & $\begin{array}{c}5.03 \\
(2.23)\end{array}$ & $\begin{array}{c}8.10 \\
(2.84)\end{array}$ & $\begin{array}{c}6.56 \\
(2.56)\end{array}$ & $\begin{array}{c}7.02 \\
(2.65)\end{array}$ \\
\hline $\mathrm{M}_{7}$ & $\begin{array}{c}6.92 \\
(2.63)\end{array}$ & $\begin{array}{c}5.73 \\
(2.39)\end{array}$ & $\begin{array}{c}7.84 \\
(2.80)\end{array}$ & $\begin{array}{c}6.83 \\
(2.61)\end{array}$ & $\begin{array}{c}6.18 \\
(2.48)\end{array}$ & $\begin{array}{c}4.74 \\
(2.17)\end{array}$ & $\begin{array}{c}7.61 \\
(2.76)\end{array}$ & $\begin{array}{c}6.18 \\
(2.48)\end{array}$ & $\begin{array}{c}6.50 \\
(2.55)\end{array}$ \\
\hline FP & $\begin{array}{l}26.48 \\
(5.15)\end{array}$ & $\begin{array}{l}22.38 \\
(4.73)\end{array}$ & $\begin{array}{l}31.85 \\
(5.64)\end{array}$ & $\begin{array}{l}26.90 \\
(5.19)\end{array}$ & $\begin{array}{l}24.64 \\
(4.96)\end{array}$ & $\begin{array}{c}19.81 \\
(4.45)\end{array}$ & $\begin{array}{l}30.69 \\
(5.54)\end{array}$ & $\begin{array}{l}25.04 \\
(5.00)\end{array}$ & $\begin{array}{l}25.97 \\
(5.10)\end{array}$ \\
\hline $\mathrm{SEm} \pm$ & 0.05 & 0.06 & 0.05 & 0.02 & 0.06 & 0.07 & 0.05 & 0.04 & 0.02 \\
\hline $\mathrm{CD}(p=0.05)$ & 0.16 & 0.19 & 0.15 & 0.07 & 0.17 & 0.21 & 0.16 & 0.11 & 0.10 \\
\hline
\end{tabular}

"Figures in the parentheses are the $\sqrt{ } \mathrm{x}+0.5$ transformed values), FP: farmers' practice

On the contrary, the highest fruit damage was observed in farmers' practice (26.90\% infested fruits on weight basis) despite of repeated application of insecticides. The biointensive modules were also offered good control of the BSFB (14.64 to $19.18 \%$ fruit damage) over farmers' practice and but found to be less effective than the other modules. During 2010-11 (pooled mean of three seasons' data) (Table 2), the module $\mathrm{M}_{7}$ retained its superiority by recording the lowest fruit damage of $6.18 \%$ (on weight basis) closely followed by $M_{6}$ (6.56\% fruit damage) and both the modules were statistically comparable with each other. The module $\mathrm{M}_{4}(6.89 \%$ fruit damage) and $\mathrm{M}_{5}(10.34 \%)$ followed in order of their efficacy. Among the bio-intensive modules the module $\mathrm{M}_{2}$ registered the lowest fruit damage of $14.08 \%$ followed by $\mathrm{M}_{3}(14.50 \%$ fruit damage) and $M_{1}(17.51 \%$ fruit damage), whereas maximum fruit infestation was observed in the farmers' practice $(25.04 \%$ fruit damage). The pooled mean value of the results of both the years of experiment ( 2009-10 and 2010-11) indicated that IPM modules $\mathrm{M}_{7}, \mathrm{M}_{6}$ and $\mathrm{M}_{4}$ significantly suppressed the fruit infestation in brinjal with only $6.50,7.02$ and $7.11 \%$ fruit damage, respectively as against $25.97 \%$ fruit damage in the farmers' practice of indiscriminate application of insecticides. These three IPM modules established themselves as the most effective IPM modules against brinjal shoot and fruit borer during the entire period of investigation. The bio-intensive modules also found to be significantly better than the farmers' practice (14.36\% in $\mathrm{M}_{2}$ to $18.34 \%$ fruit damage in $\mathrm{M}_{1}$ ) and reduced the borer incidence through an eco-friendly manner.

The results of the investigation are in close conformity with the findings of Kalawate and Dethe (2012), who opined that Spinosad was found to be the most effective against BSFB and afforded moderate control of jassid, whitefly and aphid. Dutta et al. (2011) revealed that installation of 65 pheromone traps per hectare reduced the shoot and fruit damage to 58.39 and $38.17 \%$ respectively. Elanchezhyan et al. (2008) observed that when brinjal intercropped with cluster bean at 4:1 ratio 
the incidence of Leucinodes orbonalis Gueene was very much minimized with $51.94 \%$ reduction in fruit damage by weight basis over the brinjal pure crop. Saimandir and Gopal (2009) also substantiated the findings by reporting that application of indoxacarb $14.5 \% \mathrm{SC}$ at 75 and $150 \mathrm{~g}$ a.i. ha ${ }^{-1}$ was highly effective in minimizing the fruit infestation in brinjal. Misra (2008) also reported that rynaxypyr and flubendiamide gave $87-90 \%$ reduction in eggplant fruit damage. Sharma and Sinha (2009) also concluded that brinjal border cropped with maize baby corn along with two foliar sprays of spinosad @ $75 \mathrm{~g}$ a.i. ha $^{-1}$ was very effective in minimizing the fruit borer incidence $4.93 \%$ on weight basis compared to $13.92 \%$ fruit damage in the untreated control. The findings are also supported by the results of Prasad et al., 2010 who reported that brinjal when intercropped with coriander in 3:1 ratio reduced fruit damage by 55.54 and $63.97 \%$, respectively during 2003 and 2004 . The efficacy of bio-intensive IPM modules was also mentioned by Mandal et al. (2009) who reported that bio-intensive
IPM module (Installation of sex pheromone trap+clipping of infested shoots and discarding of damaged fruits+spraying of azadirachtin $0.15 \%$ ) reduced the fruit damage to $15.80 \%$ (63.48\% reduction over control).

The population of whiteflies in brinjal was suppressed in all the IPM plots compared to farmers' practice and a significant difference in their population was observed among the different modules under study (Table 3 ). The pooled mean value during 2009-10 indicated that among the IPM modules, $\mathrm{M}_{4}$ afforded maximum control of whiteflies with an average of 0.7 flies $/ 3$ leaves followed by $M_{7}$ (1.01 flies $/ 3$ leaves), $M_{6}$ (1.03 flies $/ 3$ leaves) and $\mathrm{M}_{5}$ (1.17 flies $/ 3$ leaves). In contrast the bio-intensive IPM modules afforded a moderate control of whiteflies ( 1.55 to 1.85 flies/3 leaves) compared to 2.87 in farmers' practice. During 2010-11 all the IPM modules retained their order of efficacy similar to 2009-10 with the lowest white fly population per three leaves $(0.71)$ in $\mathrm{M}_{4}$ and that of highest (2.95) in the farmers' practice. The pooled

\begin{tabular}{|c|c|c|c|c|c|c|c|c|c|}
\hline \multirow{2}{*}{$\begin{array}{l}\text { IPM } \\
\text { Modules }\end{array}$} & \multicolumn{4}{|c|}{ No./3 leaves plant ${ }^{-1}(2009-10)$} & \multicolumn{4}{|c|}{ No./3 leaves plant ${ }^{-1}(2010-11)$} & \multirow{2}{*}{$\begin{array}{l}\text { Pooled mean (2009 } \\
10 \& 2010-11)\end{array}$} \\
\hline & Kharif & Rabi & Summer & Pooled mean & Kharif & $R a b i$ & Summer & Pooled mean & \\
\hline $\mathrm{M}_{1}$ & $\begin{array}{c}1.38 \\
(1.37)\end{array}$ & $\begin{array}{c}2.09 \\
(1.61)\end{array}$ & $\begin{array}{c}1.19 \\
(1.30)\end{array}$ & $\begin{array}{c}1.55 \\
(1.43)\end{array}$ & $\begin{array}{c}1.70 \\
(1.48)\end{array}$ & $\begin{array}{c}1.94 \\
(1.56)\end{array}$ & $\begin{array}{c}1.02 \\
(1.23)\end{array}$ & $\begin{array}{c}1.55 \\
(1.43)\end{array}$ & $\begin{array}{c}1.55 \\
(1.25)\end{array}$ \\
\hline $\mathrm{M}_{2}$ & $\begin{array}{c}1.59 \\
(1.44)\end{array}$ & $\begin{array}{c}2.56 \\
(1.75)\end{array}$ & $\begin{array}{c}1.42 \\
(1.38)\end{array}$ & $\begin{array}{c}1.85 \\
(1.53)\end{array}$ & $\begin{array}{c}1.96 \\
(1.57)\end{array}$ & $\begin{array}{c}2.38 \\
(1.70)\end{array}$ & $\begin{array}{c}1.16 \\
(1.29)\end{array}$ & $\begin{array}{c}1.83 \\
(1.53)\end{array}$ & $\begin{array}{c}1.84 \\
(1.36)\end{array}$ \\
\hline $\mathrm{M}_{3}$ & $\begin{array}{c}1.32 \\
(1.35)\end{array}$ & $\begin{array}{c}2.14 \\
(1.62)\end{array}$ & $\begin{array}{c}1.21 \\
(1.31)\end{array}$ & $\begin{array}{c}1.55 \\
(1.43)\end{array}$ & $\begin{array}{c}1.74 \\
(1.49)\end{array}$ & $\begin{array}{c}2.07 \\
(1.60)\end{array}$ & $\begin{array}{c}1.04 \\
(1.24)\end{array}$ & $\begin{array}{c}1.61 \\
(1.45)\end{array}$ & $\begin{array}{c}1.58 \\
(1.26)\end{array}$ \\
\hline $\mathrm{M}_{4}$ & $\begin{array}{c}0.70 \\
(1.09)\end{array}$ & $\begin{array}{c}0.92 \\
(1.19)\end{array}$ & $\begin{array}{c}0.49 \\
(0.99)\end{array}$ & $\begin{array}{c}0.70 \\
(1.10)\end{array}$ & $\begin{array}{c}0.74 \\
(1.11)\end{array}$ & $\begin{array}{c}0.96 \\
(1.21)\end{array}$ & $\begin{array}{c}0.43 \\
(0.96)\end{array}$ & $\begin{array}{c}0.71 \\
(1.10)\end{array}$ & $\begin{array}{c}0.71 \\
(0.84)\end{array}$ \\
\hline $\mathrm{M}_{5}$ & $\begin{array}{c}1.04 \\
(1.24)\end{array}$ & $\begin{array}{c}1.57 \\
(1.44)\end{array}$ & $\begin{array}{c}0.92 \\
(1.19)\end{array}$ & $\begin{array}{c}1.17 \\
(1.29)\end{array}$ & $\begin{array}{c}1.13 \\
(1.27)\end{array}$ & $\begin{array}{c}1.52 \\
(1.42)\end{array}$ & $\begin{array}{c}0.84 \\
(1.15)\end{array}$ & $\begin{array}{c}1.16 \\
(1.29)\end{array}$ & $\begin{array}{c}1.17 \\
(1.08)\end{array}$ \\
\hline $\mathrm{M}_{6}$ & $\begin{array}{c}0.97 \\
(1.21)\end{array}$ & $\begin{array}{c}1.35 \\
(1.36)\end{array}$ & $\begin{array}{c}0.77 \\
(1.12)\end{array}$ & $\begin{array}{c}1.03 \\
(1.23)\end{array}$ & $\begin{array}{c}0.98 \\
(1.21)\end{array}$ & $\begin{array}{c}1.42 \\
(1.38)\end{array}$ & $\begin{array}{c}0.52 \\
(1.01)\end{array}$ & $\begin{array}{c}0.97 \\
(1.21)\end{array}$ & $\begin{array}{c}1.00 \\
(1.00)\end{array}$ \\
\hline $\mathrm{M}_{7}$ & $\begin{array}{c}0.93 \\
(1.20)\end{array}$ & $\begin{array}{c}1.30 \\
(1.34)\end{array}$ & $\begin{array}{c}0.80 \\
(1.14)\end{array}$ & $\begin{array}{c}1.01 \\
(1.23)\end{array}$ & $\begin{array}{c}1.03 \\
(1.23)\end{array}$ & $\begin{array}{c}1.03 \\
(1.23)\end{array}$ & $\begin{array}{c}0.74 \\
(1.11)\end{array}$ & $\begin{array}{c}0.93 \\
(1.19)\end{array}$ & $\begin{array}{c}0.97 \\
(0.98)\end{array}$ \\
\hline FP & $\begin{array}{c}2.78 \\
(1.81)\end{array}$ & $\begin{array}{c}3.67 \\
(2.04)\end{array}$ & $\begin{array}{c}2.16 \\
(1.63)\end{array}$ & $\begin{array}{c}2.87 \\
(1.83)\end{array}$ & $\begin{array}{c}3.02 \\
(1.88)\end{array}$ & $\begin{array}{c}3.88 \\
(2.09)\end{array}$ & $\begin{array}{c}1.96 \\
(1.57)\end{array}$ & $\begin{array}{c}2.95 \\
(1.86)\end{array}$ & $\begin{array}{c}2.91 \\
(1.71)\end{array}$ \\
\hline $\operatorname{SEm} \pm$ & 0.03 & 0.05 & 0.03 & 0.03 & 0.04 & 0.04 & 0.03 & 0.02 & 0.02 \\
\hline $\mathrm{CD}(p=0.05)$ & 0.09 & 0.14 & 0.08 & 0.07 & 0.10 & 0.12 & 0.09 & 0.06 & 0.05 \\
\hline
\end{tabular}

"Average no. of white flies 3 leaves $^{-1}$ plant $^{-1}$ (Figures in the parentheses are the $\sqrt{ } \mathrm{x}+0.5$ transformed values); FP: farmers' practice

analysis of two years data indicated the superiority of $\mathrm{M}_{4}$ in the control of white flies ( 0.71 flies $/ 3$ leaves) followed by $\mathrm{M}_{7}$ (0.97), $\mathrm{M}_{6}(1.0), \mathrm{M}_{5}$ (1.17). The bio-intensive modules also offered a moderate control of white flies (1.55 to 1.84 flies/3 leaves) compared to 2.91 in farmers' practice.

During 2009-10 a significantly lower population of jassids was observed in all the IPM plots compared to the farmers' practice (Table 4). The cumulative mean population of jassids was found to be lowest in $\mathrm{M}_{4}$ (5.36 jassids/ 3 leaves) followed by $M_{7}(6.02), M_{6}(6.38)$ and $M_{5}(6.90)$ indicating the effectiveness of the IPM modules in reducing the leafhopper population. However, farmers practice recorded significantly highest jassids population of $13.21 / 3$ leaves. The pooled mean value of jassid population during 2010-11 indicated the superiority of the IPM module $\mathrm{M}_{6}$ in minimizing the jassid incidence in brinjal with 4.83 jassids $/ 3$ leaves. The other modules in order 


\begin{tabular}{|c|c|c|c|c|c|c|c|c|c|}
\hline \multirow{2}{*}{$\begin{array}{l}\text { IPM } \\
\text { modules }\end{array}$} & \multicolumn{4}{|c|}{ No./3 leaves plant ${ }^{-1}(2009-10)$} & \multicolumn{4}{|c|}{ No./3 leaves plant ${ }^{-1}(2010-11)$} & \multirow{2}{*}{$\begin{array}{l}\text { Pooled mean (2009- } \\
\quad 10 \& 2010-11)\end{array}$} \\
\hline & Kharif & Rabi & Summer & Pooled mean & Kharif & Rabi & Summer & Pooled mean & \\
\hline $\mathrm{M}_{1}$ & $\begin{array}{l}10.04 \\
(3.25)\end{array}$ & $\begin{array}{c}8.47 \\
(2.99)\end{array}$ & $\begin{array}{c}6.94 \\
(2.72)\end{array}$ & $\begin{array}{c}8.48 \\
(3.00)\end{array}$ & $\begin{array}{l}7.56 \\
(2.84)\end{array}$ & $\begin{array}{l}7.16 \\
(2.77)\end{array}$ & $\begin{array}{c}8.02 \\
(2.92)\end{array}$ & $\begin{array}{l}7.58 \\
(2.84)\end{array}$ & $\begin{array}{l}8.03 \\
(2.83)\end{array}$ \\
\hline $\mathrm{M}_{2}$ & $\begin{array}{l}10.85 \\
(3.37)\end{array}$ & $\begin{array}{c}9.35 \\
(3.14)\end{array}$ & $\begin{array}{c}7.43 \\
(2.81)\end{array}$ & $\begin{array}{c}9.21 \\
(3.12)\end{array}$ & $\begin{array}{c}8.35 \\
(2.97)\end{array}$ & $\begin{array}{c}7.92 \\
(2.90)\end{array}$ & $\begin{array}{c}8.80 \\
(3.05)\end{array}$ & $\begin{array}{c}8.36 \\
(2.98)\end{array}$ & $\begin{array}{l}8.78 \\
(2.96)\end{array}$ \\
\hline $\mathrm{M}_{3}$ & $\begin{array}{c}9.90 \\
(3.22)\end{array}$ & $\begin{array}{c}8.19 \\
(2.94)\end{array}$ & $\begin{array}{l}7.08 \\
(2.75)\end{array}$ & $\begin{array}{l}8.39 \\
(2.98)\end{array}$ & $\begin{array}{l}7.40 \\
(2.80)\end{array}$ & $\begin{array}{l}7.38 \\
(2.81)\end{array}$ & $\begin{array}{l}7.71 \\
(2.86)\end{array}$ & $\begin{array}{c}7.50 \\
(2.83)\end{array}$ & $\begin{array}{c}7.94 \\
(2.82)\end{array}$ \\
\hline $\mathrm{M}_{4}$ & $\begin{array}{c}6.15 \\
(2.57)\end{array}$ & $\begin{array}{c}5.08 \\
(2.36)\end{array}$ & $\begin{array}{c}4.85 \\
(2.31)\end{array}$ & $\begin{array}{c}5.36 \\
(2.42)\end{array}$ & $\begin{array}{c}5.03 \\
(2.35)\end{array}$ & $\begin{array}{c}4.87 \\
(2.31)\end{array}$ & $\begin{array}{l}4.96 \\
(2.33)\end{array}$ & $\begin{array}{l}4.95 \\
(2.33)\end{array}$ & $\begin{array}{l}5.15 \\
(2.27)\end{array}$ \\
\hline $\mathrm{M}_{5}$ & $\begin{array}{c}8.35 \\
(2.97)\end{array}$ & $\begin{array}{c}6.40 \\
(2.62)\end{array}$ & $\begin{array}{l}5.95 \\
(2.54)\end{array}$ & $\begin{array}{c}6.90 \\
(2.72)\end{array}$ & $\begin{array}{c}5.91 \\
(2.53)\end{array}$ & $\begin{array}{c}5.71 \\
(2.49)\end{array}$ & $\begin{array}{l}5.95 \\
(2.54)\end{array}$ & $\begin{array}{l}5.86 \\
(2.52)\end{array}$ & $\begin{array}{c}6.38 \\
(2.52)\end{array}$ \\
\hline $\mathrm{M}_{6}$ & $\begin{array}{l}7.65 \\
(2.85)\end{array}$ & $\begin{array}{c}6.13 \\
(2.57)\end{array}$ & $\begin{array}{c}5.38 \\
(2.42)\end{array}$ & $\begin{array}{c}6.38 \\
(2.62)\end{array}$ & $\begin{array}{c}4.83 \\
(2.30)\end{array}$ & $\begin{array}{l}5.03 \\
(2.35)\end{array}$ & $\begin{array}{c}4.64 \\
(2.26)\end{array}$ & $\begin{array}{c}4.83 \\
(2.31)\end{array}$ & $\begin{array}{c}5.61 \\
(2.37)\end{array}$ \\
\hline $\mathrm{M}_{7}$ & $\begin{array}{l}7.30 \\
(2.79)\end{array}$ & $\begin{array}{c}5.65 \\
(2.48)\end{array}$ & $\begin{array}{l}5.10 \\
(2.36)\end{array}$ & $\begin{array}{c}6.02 \\
(2.55)\end{array}$ & $\begin{array}{c}5.48 \\
(2.44)\end{array}$ & $\begin{array}{c}4.53 \\
(2.24)\end{array}$ & $\begin{array}{l}5.48 \\
(2.44)\end{array}$ & $\begin{array}{c}5.16 \\
(2.38)\end{array}$ & $\begin{array}{l}5.59 \\
(2.36)\end{array}$ \\
\hline FP & $\begin{array}{l}15.68 \\
(4.02)\end{array}$ & $\begin{array}{l}12.65 \\
(3.62)\end{array}$ & $\begin{array}{l}11.30 \\
(3.43)\end{array}$ & $\begin{array}{l}13.21 \\
(3.70)\end{array}$ & $\begin{array}{l}13.63 \\
(3.76)\end{array}$ & $\begin{array}{l}10.91 \\
(3.37)\end{array}$ & $\begin{array}{l}11.78 \\
(3.50)\end{array}$ & $\begin{array}{l}12.11 \\
(3.55)\end{array}$ & $\begin{array}{l}12.66 \\
(3.56)\end{array}$ \\
\hline $\operatorname{SEm} \pm$ & 0.08 & 0.07 & 0.07 & 0.05 & 0.08 & 0.06 & 0.06 & 0.04 & 0.04 \\
\hline $\mathrm{CD}(p=0.05)$ & 0.24 & 0.21 & 0.21 & 0.15 & 0.22 & 0.18 & 0.18 & 0.13 & 0.12 \\
\hline
\end{tabular}

*Average no. of jassids 3 leaves ${ }^{-1}$ plant $^{-1}$ (Figures in the parentheses are the $\sqrt{ } \mathrm{x}+0.5$ transformed values); FP: farmers' practice

of their efficacy against jassids were $\mathrm{M}_{4}, \mathrm{M}_{7}$ and $\mathrm{M}_{5}$ with 4.95 , 5.16 and 5.86 jassids/ 3 leaves, respectively. The analysis of pooled data of 2009-10 and 2010-11 revealed that all the modules were superior to the farmers' practice and the module $\mathrm{M}_{4}$ was the most effective with significantly lowest jassid population of $5.15 / 3$ leaves.

The above findings are in accordance with the findings of Sinha and Vishwa (2011) who opined that indoxacarb @ 70 g a.i. ha ${ }^{-1}$ was very effective in managing the population of sucking pests.
Sardana et al. (2009), observed that IPM practice consisting of soil application of neem cake, foliar application of 5\% NSKE, release of egg parasitoid T. brasiliensis, clipping of damaged shoots and destruction of infested fruits, installation of pheromone trap, delta traps and bird perches and need based application of imidacloprid 17.8 SL@0.5 $\mathrm{ml} \mathrm{l}^{-1}$ water significantly minimized the leaf hoppers and aphids in brinjal. It is evidenced from the findings that (Table 5) the lower pest incidence in the IPM plots contributed to higher fruit yield

\begin{tabular}{|c|c|c|c|c|c|c|c|c|c|}
\hline \multirow{2}{*}{$\begin{array}{l}\text { IPM } \\
\text { modules }\end{array}$} & \multicolumn{4}{|c|}{ 2009-10 } & \multicolumn{4}{|c|}{ 2010-11 } & \multirow{2}{*}{$\begin{array}{l}\text { Pooled mean (2009- } \\
\quad 10 \& 2010-11)\end{array}$} \\
\hline & Kharif & Rabi & Summer & Pooled mean & Kharif & Rabi & Summer & Pooled mean & \\
\hline $\mathrm{M}_{1}$ & 213.25 & 227.24 & 197.16 & 212.55 & 217.42 & 235.13 & 203.29 & 218.61 & 215.58 \\
\hline $\mathrm{M}_{2}$ & 224.08 & 239.44 & 211.36 & 224.96 & 227.54 & 243.55 & 214.12 & 228.40 & 226.68 \\
\hline $\mathrm{M}_{3}$ & 223.26 & 238.78 & 210.52 & 224.19 & 226.51 & 242.60 & 213.16 & 227.42 & 225.80 \\
\hline $\mathrm{M}_{4}$ & 244.91 & 263.20 & 227.97 & 245.36 & 247.39 & 266.33 & 227.87 & 247.19 & 246.28 \\
\hline $\mathrm{M}_{5}$ & 235.27 & 255.12 & 220.95 & 237.11 & 238.64 & 258.64 & 221.60 & 239.63 & 238.37 \\
\hline $\mathrm{M}_{6}$ & 244.26 & 262.59 & 227.21 & 244.69 & 247.92 & 267.61 & 229.02 & 248.18 & 246.44 \\
\hline $\mathrm{M}_{7}$ & 245.79 & 264.17 & 228.62 & 246.19 & 248.60 & 268.47 & 229.75 & 248.94 & 247.57 \\
\hline FP & 187.70 & 195.42 & 171.88 & 185.00 & 191.08 & 199.40 & 176.93 & 189.14 & 187.07 \\
\hline $\mathrm{SEm} \pm$ & 0.65 & 0.59 & 0.68 & 0.35 & 0.66 & 0.73 & 0.77 & 0.39 & 0.27 \\
\hline $\mathrm{CD}(p=0.05)$ & 1.92 & 1.73 & 2.01 & 1.03 & 1.94 & 2.14 & 2.25 & 1.15 & 0.80 \\
\hline
\end{tabular}

FP: farmers' practice 
in brinjal. The pooled mean value over the three seasons of 2009-10 revealed that the module $M_{7}$ registered the highest total fruit yield of $246.19 \mathrm{q} \mathrm{ha}^{-1}$ and was statistically comparable with $\mathrm{M}_{4}\left(245.36 \mathrm{q} \mathrm{ha}^{-1}\right)$. Fruit yield of $244.69 \mathrm{q} \mathrm{ha}^{-1}$ obtained from $M_{6}$ was next in order and statistically on par with $M_{4}$. The bio-intensive modules also recorded better fruit yield ranging from $212.55 \mathrm{q} \mathrm{ha}^{-1}$ in $\mathrm{M}_{1}$ to $224.96 \mathrm{q} \mathrm{ha}^{-1}$ in $\mathrm{M}_{2}$ and were superior to farmers' practice $\left(185.00 \mathrm{q} \mathrm{ha}^{-1}\right)$. The pooled analysis of data on fruit yield of all the seasons of 2010-11 also evidently proved the superiority of the module $M_{7}$ over the rest of the treatments as it registered the highest fruit yield of 248.94. The module $\mathrm{M}_{6}$ was found to be the next better IPM option (fruit yield of 248.18) and was statistically similar with $M_{7}$. The module $M_{4}$ was also found to be effective in increasing the fruit yield ( $\left.247.19 \mathrm{q} \mathrm{ha}^{-1}\right)$ in brinjal and was on par with the module $\mathrm{M}_{6}$. In the bio-intensive IPM modules the total yield ranged from $218.61 \mathrm{q} \mathrm{ha}^{-1}$ in $\mathrm{M}_{1}$ to $228.40 \mathrm{q} \mathrm{ha}^{-1}$ in $\mathrm{M}_{2}$. The pooled mean data of both the years of investigation indicated the higher efficacy of IPM modules in increasing the fruit yield in brinjal crop ( $247.57 \mathrm{q} \mathrm{ha}^{-1}$ in $\mathrm{M}_{7}$ to $215.58 \mathrm{q} \mathrm{ha}^{-1}$ in $\mathrm{M}_{1}$ ) over the farmers' practice (187.07 $\left.\mathrm{q} \mathrm{ha}^{-1}\right)$ of repeated application of insecticides.

\section{Conclusion}

Soil application of cartap hydrochloride 4 G @ 1 kg a.i. ha ${ }^{-1}$ at 2 weeks of transplanting, Intercropping with coriander in 3:1 ratio, Alternate foliar spray of indoxacarb14.5 SC@1 $\mathrm{ml} \mathrm{l}^{-1}$ of water and rynaxypyr $20 \mathrm{SC} @ 0.35 \mathrm{ml} \mathrm{l}^{-1}$ of water at 10 days interval twice at vegetative stage and six times were also found to be highly effective in suppressing the infestation of shoot and fruit borer and the population of sucking insect pests infesting brinjal

\section{References}

Dutta, P., Singh, A.K., Das, P., Kalita, S., 2011. Management of brinjal fruit and shoot borer, Leucinodes orbanalis Guenee in agro-ecological condition of West Tripura. Scholarly Journal of Agricultural Science 1(2), 16-19.

Elanchezhyan, K., Murali Baskaran, R.K., Rajavel, D.S., 2008. Influence of Intercrops on Incidence of Major Pests of Brinjal and their Natural Enemies. Annals of Plant
Protection Sciences 16(1), 87-91.

Haseeb, M., Sharma, D.K., Qamar, M., 2009. Estimation of the losses caused by shoot and fruit borer, Leucinodes orbonalis Guen. (Lepidoptera: Pyralidae) in egg plant. Trends Bioscience 2, 68-69.

Kalawate, A., Dethe, M.D., 2012. Bioefficacy study of biorational insecticide on brinjal. Journal of Biopesticides 5(1), 75-80.

Mandal, S.K., Kumar, R., Das, S., Kumar, V., 2009. Field evaluation of integrated pest management modules for the brinjal shoot and fruit borer, Leucinodes orbonalis Guenee. Pest Management and Economic Zoology 17(2), 121-125.

Misra, H.P., 2008. New promising insecticides for the management of brinjal shoot and fruit borer, Leucinodes orbonalis Guenee. Pest Management in Horticulture Ecosystems 14(2), 140-147.

Patial, A., Mehta, P.K., 2008. Pest complex of brinjal and their succession under mid hills of Himachal Pradesh. Journal of Insect Sciences 21(1), 67-71.

Prasad, R., Prasad, U.K., Prasad, D., 2010. Relative efficacy of inter-cropping and judicious use of insecticides against Leucinodes orbonalis Guenee infesting brinjal for its sustainable cultivation. Journal of Eco-friendly Agriculture 5(2), 160-161.

Saimandir, J., Gopal, M., 2009. Application of indoxacarb for managing shoot and fruit borer of eggplant (Solanum melongena L.) and its decontamination. Journal of Environment Science and Health 44(3), 292-301.

Sardana, H.R., Bambawale, O.M., Jalali, S.K., 2009. Validation of non-chemical IPM and INM technologies on brinjal through farmer participatory approach. Indian Journal of Plant Protection 37(1\&2), 20-23.

Sharma, R.K., Sinha, S.R., 2009. Management of shoot and fruit borer Leucinodes orbonalis Guen. through border cropping and insecticides in Brinjal. Indian Journal of Entomology 71(2), 130-132.

Sinha, S.R., Vishwa, N., 2011. Management of Insect Pests through Insecticides and Mixture in Brinjal. Annals of Plant Protection Sciences 19(2), 318-320. 